Ways of Writing 
MATERIAL TEXTS

SERIES EDITORS

$\begin{array}{ll}\text { Roger Chartier } & \text { Anthony Grafton } \\ \text { Joan DeJean } & \text { Janice Radway } \\ \text { Joseph Farrell } & \text { Peter Stallybrass }\end{array}$

A complete list of books in the series is available from the publisher. 


\section{Ways of Writing}

The Practice and Politics of Text-Making in Seventeenth-Century New England

David D. Hall

\section{$\overline{\text { PENN }}$}

University of Pennsylvania Press

Philadelphia 
Copyright (C) 2008 University of Pennsylvania Press

All rights reserved. Except for brief quotations used for purposes of review or scholarly citation, none of this book may be reproduced in any form by any means without written permission from the publisher.

Published by

University of Pennsylvania Press

Philadelphia, Pennsylvania I9IO4-4II2

Printed in the United States of America on acid-free paper

IO $\quad 9 \begin{array}{lllllllll} & 8 & 7 & 6 & 5 & 4 & 3 & 2 & \text { I }\end{array}$

Library of Congress Cataloging-in-Publication Data

Hall, David D.

Ways of writing : the practice and politics of text-making in seventeenth-century New England / David D. Hall.

p. cm.-(Material texts)

Includes bibliographical references and index.

ISBN 978-0-8I22-4IO2-o (alk. paper)

I. Book industries and trade-New England-History—-I7th century. 2. Authorship-Social aspects—New England-History — I7th century. 3. Transmission of texts-New England-History-I7th century. 4. New England-Intellectual life-I7th century. I. Title. $\mathrm{Z}_{473 . \mathrm{H} 23 \quad 2008}$ $38 \mathrm{I}^{\prime} \cdot 45002097409032-\mathrm{dc22}$ 
In memory of

Roland Andre Delattre

sans pareil 
